splenectomy in a laparotomy performed for another purpose appear to be particularly hazardous. ${ }^{26}$ Four of 12 hyposplenic patients submitted to colectomy for inflammatory bowel disease developed clinical features of the overwhelming postsplenectomy infection syndrome with disseminated intravascular coagulation, ${ }^{27}$ and subcutaneous heparin may have a role in prophylaxis perioperatively in such patients.

Can severe infection after splenectomy be prevented? Penicillin prophylaxis seems reasonable in children to reduce the risk of pneumococcal infection. Active immunisation with pneumococcal vaccines should certainly be considered. Unfortunately, antibody responses are impaired in asplenia. ${ }^{28} 29$ Furthermore, not all serotypes which may cause disease have been included in current vaccines. The vaccine commercially available in Britain did not contain the antigen type that produced fatal pneumococcal septicaemia in a 22 -year-old English woman with ulcerative colitis and splenic atrophy. ${ }^{\mathbf{3 0}}$ Nevertheless, asplenic patients should be sought out and immunised with existing vaccines, and pneumococcal vaccination should be performed before an elective splenectomy. Patients who have had a splenectomy or who have developed hyposplenism must be identified as being at special risk. Their general practitioners should be advised that if they develop an unexplained illness with shock, blood should be taken immediately for culture, and empirical treatment of the presumptive pneumococcal or haemophilus septicaemia should be started without delay-a suitable regimen is the combination of benzylpenicillin with amoxycillin.

ANNE FERGUSON

Reader in Medicine,

Gastrointestinal Unit,

Western General Hospital and University of Edinburgh,

Edinburgh EH4 2XU

1 Eppinger H. Zur pathologie der milzfunktion. Klin Wochenschr 1913;50: 1509-12.

2 Schilling V. Uber die diagnose einer milzatrophie durch den befund von kernkugeln als teilerscheinung pluriglandularer insuffizienz. Klin Wochenschr 1924;43:1960-2.

${ }^{3}$ Wasi C, Wasi P, Thongcharoen P. Serum-immunoglobulin levels in thalassaemia and the effects of splenectomy. Lancet 1971 ;ii:237-9.

4 Baker PG, Jones JV, Peacock DB, Read AE. The immune response to $\phi \mathrm{X} 174$ in man. III. Evidence for an association between hyposplenism and immunodeficiency in patients with coeliac disease. Gut 1975;16: 538-42.

${ }^{5}$ Majeski JA, Upshur JK. Asplenia syndrome. A study of congenital anomalies in 16 cases. $\mathcal{F} A M A 1978 ; 240: 1508-10$.

- Ferguson A, Hutton MM, Maxwell JD, Murray D. Adult coeliac disease in hyposplenic patients. Lancet 1970;i:163-4.

7 Bullen AW, Hall R, Gowland G, Rajah S, Losowsky MS. Hyposplenism, adult coeliac disease, and autoimmunity. Gut $1981 ; 22: 28-33$.

${ }^{8}$ McCarthy CF, Fraser ID, Evans KT, Read AE. Lymphoreticular dysfunction in idiopathic steatorrhoea. Gut 1966;7:140-8.

${ }^{9}$ Marsh GW, Stewart JS. Splenic function in adult coeliac disease. $\mathrm{Br} \mathcal{F}$ Haematol 1970;19:445-57.

10 Pettit JE, Hoffbrand AV, Seah PP, Fry L. Splenic atrophy in dermatitis herpetiformis. $\mathrm{Br} \mathrm{Med} \mathcal{F} 1972$;ii:438-40.

11 Ferguson A. Coeliac disease and gastrointestinal food allergy. In: Ferguson A, MacSween RNM, eds. Immunological aspects of the liver and gastrointestinal tract. Lancaster: MTP Press Ltd, 1976:153-202.

12 Trewby PN, Chipping PM, Palmer SJ, Roberts PD, Lewis SM, Stewart JS Splenic atrophy in adult coeliac disease: is it reversible? Gut 1981; 22:628-32.

${ }^{13}$ Ryan FP, Smart RC, Preston FE, Holdsworth CD. Hyposplenism in ulcerative colitis. Lancet $1974 ;$ ii :318-20.

14 Ardeman S, Bevan G. Hyposplenism and ulcerative colitis. Lancet $1974 ;$ ii :588.

15 Ryan FP, Smart RC, Holdsworth CD, Preston FE. Hyposplenism in inflammatory bowel disease. Gut 1978;19:50-5.

16 Pearson HA, Spencer RP, Cornelius EA. Functional asplenia in sickle-cell anemia. N Engl f Med 1969;281:923-6.

17 Diamond LK. Splenectomy in childhood and the hazard of overwhelming infection. Pediatrics $1969 ; 43: 886-9$.

18 Bisno AL, Freeman JC. The syndrome of asplenia, pneumococcal sepsis, and disseminated intravascular coagulation. Ann Intern Med 1970; 72:389-93.

19 Ramsay LE. Infections in asplenic adults. $B r$ Med $\mathcal{f} 1974$;iii:254-5.
${ }^{20}$ Holmes FF, Weyandt T, Glazier J, Cuppage FE, Moral LA, Lindsey NJ. Fulminant meningococcemia after splenectomy. $\mathcal{F} A M A$ 1981;246: 1119-20.

${ }^{21}$ Austin TW, Sargeant HL, Warwick OH. Fulminant gonococcemia after splenectomy. Can Med Assoc F 1980;123:195-6.

${ }^{22}$ Shute PG. Splenectomy and susceptibility to malaria and babesia infection. Br Med 7 1975; :516.

${ }^{23}$ Chaves-Carballo E, Efthimiadis BK, Stockwell HP. Toxoplasmosis after splenectomy in sickle cell disease. Report of two cases with recurrence in one child two years following antitoxoplasmic therapy. Clin Pediatr 1976;15:270-2.

24 Wegelius R. Postsplenectomy infections. Lancet $1982 ; \mathrm{i}: 1420-1$.

25 Robinette CD, Fraumeni JF Jr. Splenectomy and subsequent mortality in veterans of the 1939-45 war. Lancet 1977; ii:127-9.

${ }^{26}$ Hambraeus GM, Mercke CE. Consequence of splenectomy in oesophageal carcinoma. Lancet 1979 ; : 621 .

27 Palmer KR, Sherriff SB, Holdsworth CD, Ryan FP. Further experience of hyposplenism in inflammatory bowel disease. $Q \mathcal{F}$ Med 1981 ;3:463-71.

${ }^{28} \mathrm{Schwartz} \mathrm{AD}$, Pearson HA. Impaired antibody response to intravenous immunization in sickle cell anemia. Pediatr Res 1972;6:145-9.

${ }^{29}$ Hosea SW, Burch CG, Brown EJ, Berg RA, Frank MM. Impaired immune response of splenectomised patients to polyvalent pneumococcal vaccine. Lancet 1981 ; : $804-7$.

${ }^{30}$ Foster KJ, Devitt N, Gallagher PJ, Abbott RM. Overwhelming pneumococcal septicaemia in a patient with ulcerative colitis and splenic atrophy. Gut $1982 ; 23: 630-2$.

\section{Acute cholecystitis: a case for early surgery?}

Halsted was among the first to advocate early surgery for acute cholecystitis. ${ }^{1}$ His diary for 1881 records what must have been his most memorable case: "I was summoned to Albany by telegram to see my mother-I found her very ill, slightly jaundiced, with tumefaction and great tenderness in the region of the gall bladder. So at 2 am I operated, incised the gall bladder, which was distended with pus, and extracted seven stones."2 This vivid sketch is a reminder that acute cholecystitis is almost always due to obstruction of the gall bladder by stones, that it may be dangerous, and often affects the elderly, but that urgent surgery may be life saving: Halsted's mother lived for another two years.

When Halsted's pupil G J Heuer moved to the New York Hospital he decided to adopt the policy of operating on patients with acute cholecystitis within a day or two of admission. ${ }^{1}$ Between 1932 and 1947, 586 patients underwent early surgery; in $87 \%$ a cholecystectomy was performed and in $13 \%$ who were seriously ill a cholecystostomy was done, often under local anaesthesia. ${ }^{3}$ The mortality rate was, for the time, a remarkable $3 \%$. Despite its success this policy was much criticised, and controversy about the merits of early over delayed surgery has continued ever since.

Acute cholecystitis is now the third commonest cause of emergency admission to surgical wards ${ }^{4}$ and occurs in women of all ages and in older men. ${ }^{5}$ In its most severe form, well illustrated by Mrs Halsted, $10-15 \%$ of patients show signs of peritonitis and require emergency surgery for gangrene, and in some cases perforation, of the gall bladder. Cholecystostomy, with removal of the obstructing stones, will be the only safe operation in some bacteraemic and elderly patients. Mortality in this group is now about 5\%. On rare occasions acalculous cholecystitis complicates trauma or abdominal surgery and this may also require emergency cholecystectomy. ${ }^{6}$ There is no doubt about the need for urgent surgery in some patients, but what is the correct management for the $80-90 \%$ who show progressive improvement after admission?

The first requirement is to be reasonably certain of 
the diagnosis. Halas $z^{7}$ showed that a fifth of patients, with an initial diagnosis of acute cholecystitis, were found to have disease in the right kidney, liver, or pancreas which would not have been helped by laparotomy. Several reports of trials of early surgery, however, show that careful clinical assessment results in few diagnostic errors. ${ }^{8-12}$ During the 48 hours after admission plain radiographs, routine chemical estimations of serum, microscopy of the urine, and a full blood count may be followed by ultrasonography, which can detect specific signs (stones, thickening of the wall, or increased diameter of the gall bladder). ${ }^{13}{ }^{14}$ Cholescintigraphy is a quick method of showing blockage of the cystic duct. ${ }^{13}$ This period of 48 hours is also a time of active treatment with intravenous fluids and antibiotics and careful assessment of fitness for operation.

If the diagnosis of acute cholecystitis is upheld and the patient is fit for operation "the question is whether postponement offers any advantage." 15 This cannot be answered on technical grounds because some cholecystectomies are easy and some are difficult, quite irrespective of timing, although the indications are that difficulties increase after seven to 10 days and have not always abated after two to three months ${ }^{16}$ : it is essential in all cases and at all times for an experienced surgeon either to perform or to directly supervise the operation. In $90-95 \%$ of early cholecystectomies an informative intraoperative cholangiogram may be obtained, ${ }^{10111718}$ and this is important because up to two-fifths of patients require exploration of the common duct. ${ }^{15}$ Residual stones are no more common after early than after delayed surgery. ${ }^{10111517-19}$ The crucial question of the respective mortality and morbidity rates is difficult to assess because surgery during a trial is likely to be especially careful. ${ }^{20}$ Nevertheless, there is no evidence of any appreciable difference: mortality rates of $0-1 \%$ are reported, with no record of ductal injuries. ${ }^{19}$ The advantage of early operation to both patient and hospital is that treatment is completed in one admission, ${ }^{21}$ and for a few fortunate patients there is timely removal of a gangrenous gall bladder in spite of unremarkable physical signs. Among patients who have to wait the traditional two to three months for readmission, $10-20 \%$ relapse $^{19}$ and require a second emergency admission, while the total time away from home and work is always longer. ${ }^{21}$

One of the major developments in emergency abdominal surgery over the past 20 years has been recognition of the place of definitive procedures in emergency operations for perforated peptic ulcer ${ }^{22}$ and for the obstructed or perforated colon. ${ }^{23}$ Acute cholecystitis is not usually so pressing an emergency, but the case for performing cholecystectomy on the next operating list, after two or three days of preoperative treatment and assessment, must now be considered to be established.

\section{Peter F Jones}

Consultant Surgeon,

Woodend General Hospital,

Aberdeen AB9 2YS

${ }^{1}$ Heuer GJ. Introduction to Glenn F. The surgical treatment of acute cholecystitis. Surg Gynecol Obstet 1946;83:50-4.

${ }^{2}$ MacCallum WG. William Stewart Halsted. Baltimore: Johns Hopkins Press, 1930:44.

${ }^{3}$ Glenn F. The surgical treatment of acute cholecystitis. Surgery 1948; 23:397-404.

${ }^{4}$ de Dombal FT. Diagnosis of acute abdominal pain. Edinburgh: Churchill Livingstone, 1980:17, 77 .

5 Mitchell A, Morris PJ. Hospital admissions for acute cholecystitis: changes in the age and sex distribution in Oxford in the post-wa period. Br 7 Surg 1982;69:26-8.

${ }^{6}$ Howard RJ. Acute acalculous cholecystitis. Am f Surg 1981;141:194-8.
${ }^{7}$ Halasz NA. Counterfeit cholecystitis. A common diagnostic dilemma. Am f Surg 1975;130:189-93.

${ }^{8}$ Van der Linden W, Sunzel H. Early versus delayed operation for acute cholecystitis: a controlled clinical trial. Am f Surg 1970;120:7-13.

${ }^{9}$ MacArthur P, Cuschieri A, Sells RA, Shields R. Controlled clinical trial comparing early with interval cholecystectomy for acute cholecystitis. Br F Surg 1975;62:850-2.

${ }^{10}$ Raine PAM, Gunn AA. Acute cholecystitis. Br F Surg 1975;62:697-700.

11 Lahtinen J, Alhava EM, Ankee S. Acute cholecystitis treated by early and delayed surgery: a controlled clinical trial. Scand $\mathcal{f}$ Gastroenterol $1978 ; 13: 673-8$.

12 Järvinen HJ, Hästbacka J. Early cholecystectomy for acute cholecystitis. A prospective randomized study. Ann Surg 1980;191:501-5.

13 Worthen NJ, Uszler JM, Funamara JL. Cholecystitis: prospective evaluation of sonography and $99^{\mathrm{m}}$ Tc-HIDA cholescintigraphy. $A \mathcal{F}$ 1981;137:973-8.

14 Dillon $\mathrm{H}$, Parkin GJS. The role of upper abdominal ultrasonography in suspected acute cholecystitis. Clin Radiol 1980;31:175-9.

15 Sokhi GS, Longland CJ. Early and delayed operation in acute gall-stone disease. Br $\mathcal{F}$ Surg 1973;60:937-9.

16 Ross FP, Boggs JD, Dunphy JE. Studies in acute cholecystitis. III. Pathological process in relation to clinical management of the disease; fallacy of "critical period." Surg Gynecol Obstet 1950;91:271-6.

17 Bevan PG. Acute gallbladder disease. Ann R Coll Surg Engl 1978;60:471-6.

18 Reiss R, Pikelnie S, Engelberg M. The value of early surgery and routine operative cholangiography in the management of acute cholecystitis. World $\mathcal{F}$ Surg $1979 ; 3: 107-10,136-40$.

19 Mitchell A, Morris PJ. Trends in management of acute cholecystitis. Br Med f 1982;284:27-30.

${ }^{20}$ Van der Linden W, Edlund G. Early versus delayed cholecystectomy: the effect of a change in management. Brf Surg 1981;68:753-7.

${ }^{21}$ Fowkes FGR, Gunn AA. The management of acute cholecystitis and its hospital cost. Br F Surg 1980;67:613-7.

22 Jordan GL, DeBakey ME, Duncan JM Jr. Surgical management of perforated peptic ulcer. Ann Surg 1974;179:628-33.

${ }^{23}$ Fielding LP. Primary resection for obstructed large bowel cancer. In: De Cosse JJ, ed. Large bowel cancer. Edinburgh: Churchill Livingstone, $1981: 128-43$.

\section{Magnesium deficiency and diuretics}

Identifying dangerous side effects produced by drugs is notoriously difficult. The difficulties are compounded when the drug in question is used in the long-term treatment of many patients. In these circumstances experience may be widely disseminated, and important but rare sequelae may be overlooked by individual doctors. Though oral diuretics are now in their third decade, new problems are emerging. Some, such as impotence (reported in the Medical Research Council trial $^{1}$ of treatment of mild hypertension), are quite unexpected. Other side effects are predictable in the light of the known physiological actions of diuretics, though their clinical importance may not be clear. The influence of diuretics on magnesium metabolism and the relation between magnesium and potassium deficiency belong to this second class.

Thiazide and loop diuretics acutely induce substantial urinary losses of magnesium..$^{2-4}$ Potassium-retaining diuretics probably do not have this effect ${ }^{5}$ and, indeed, may produce magnesium retention. ${ }^{6}$ The degree of magnesium depletion produced by potassium-losing diuretics is rarely severe enough to cause a classical clinical picture of magnesium deficiency with neuromuscular irritability and tetany; indeed, the condition may readily be overlooked since serum magnesium concentrations may not reflect an intracellular deficit. ${ }^{3} 7$ The belief that diuretics may have important effects on magnesium balance is supported by the finding of low magnesium concentrations in the skeletal muscle of patients undergoing prolonged diuretic treatment for congestive cardiac failure. ${ }^{89}$ In such cases, however, the magnesium deficiency may not directly be due to diuretics ${ }^{8}$ : secondary aldosteronism, protein-energy 